\title{
EFFECTIVNESS OF THE FAILURE RATE ON MAINTENANCE COSTS OF THE CITY BUSES
}

\section{WPLYW CZESTOŚCI USZKODZEŃ NA KOSZTY UTRZYMANIA AUTOBUSÓW KOMUNIKACJI MIEJSKIEJ}

\author{
Piotr Ignaciuk $^{1}$, Joanna Rymarz ${ }^{1}$, Andrzej Niewczas ${ }^{2}$ \\ ${ }^{1}$ Politechnika Lubelska, ${ }^{2}$ Wyższa Szkoła Ekonomii i Innowacji w Lublinie, \\ e-mail:j.rymarz@pollub.pl,p.ignaciuk@pollub.plandrzej.niewczas@wsei.lublin.pl
}

\begin{abstract}
The purpose of this paper was to present a failure rate and maintenance cost comparison for two types of city transport buses. The paper presents in detail a case study of well known bus brands used at Municipal Transport Company in Lublin. A failure index of all functional and constructional systems of the vehicles and their technical availability with regards to calendar time was determined. The paper also presents analysis of the factors related to maintenance costs of buses, including costs of fluids, repair costs and maintenance service. It has been demonstrated, that both analyzed buses generate similar maintenance costs, while their failures and technical availability differ significantly in operational practice. These differences are particularly evident in relation to the cumulative costs of repairs.
\end{abstract}

Keywords: city transport buses, failure index, technical availability, maintenance costs

Streszczenie: Celem pracy byto porównanie wpływu częstości uszkodzeń dwóch marek autobusów miejskich na koszty ich utrzymania. Przedstawiono szczegółowo studium przypadku na przykładzie znanych marek autobusów, użytkowanych w Miejskim Przedsiębiorstwie Komunikacyjnym w Lublinie. Wyznaczono wskaźniki uszkodzeń wszystkich układów funkcjonalno - konstrukcyjnych autobusów oraz ich gotowość techniczna $w$ funkcji czasu kalendarzowego. W artykule zaprezentowano również analize czynników związanych z kosztami eksploatacji autobusów, w tym m.in. koszty płynów eksploatacyjnych, koszty napraw i obstug. Wykazano, że $w$ praktyce eksploatacyjnej $w$ analizowanym okresie czasu pojazdy obu marek generuja podobne koszty użtkowania, natomiast ich uszkodzenia oraz gotowość techniczna różnia się znaczaco. Wymienione różnice sa szczególnie widoczne w zakresie skumulowanych kosztów napraw.

Stowa kluczowe: autobusy komunikacji miejskiej, wskaźniki uszkodzeń, gotowość techniczna, koszty utrzymania 
Effectivness of the failure rate on maintenance costs of the city buses

Wptyw częstości uszkodzeń na koszty utrzymania autobusów komunikacji miejskiej

\section{Introduction}

An effective vehicle maintenance is a main issue for each user. It is especially significant in case of utility vehicles. Each carrier selecting vehicle brand takes into account factors related to forecasted operating costs of the vehicle. Manufacturers and sellers advertising their products usually emphasize such aspects as fuel consumption and technical maintenance frequency. Since these both factors generate most of the operating costs.

In this article analysis of the factors related to operating costs of the public buses are presented. Special focus is made to factors differentiating these costs. In order to do that costs directly related to vehicle use, such as fuel costs, engine oil, and AdBlue liquid were analysed. Analysis of maintenance costs was divided into two parts: costs related to scheduled maintenance works and costs related to failures. Due to the fact that failure vehicle does not generate any income, difference in revenues obtained during the use of buses of both brands was estimated. Thus, availability ratio was analysed. The ratio was applied as a ratio of possibility of vehicle use for profit-making.

\section{Studies process}

The study included Mercedes-Benz Conecto LF 628 and Solaris Urbino 12 buses at Municipal Transport Company in Lublin [14]. The study included 22 buses of Mercedes-Benz 628 Conecto LF and 20 buses of Solaris Urbino 12. All buses were observed from the first day of the operation (January 2009 for Mercedes-Benz and June 2008 for Solaris) to the 57 months of operation and had similar vehicle mileage. The studies were conducted under natural conditions at Municipal Transport Company in Lublin.

\section{Use of operating liquids}

In the conducted analyses the costs related directly to vehicle usage included the following costs: fuel, diesel, AdBlue liquid, windshield washer fluid, air conditioning filling factor (gas and oil) and engine oil. Characteristics of fuel, AdBlue fluid, oil and number of kilometres done by the vehicles are listed in table 1. Presented data were obtained based on the analysis of the operating documentation within the period of 57 months. It can be seen that for both brands a monthly mileage was similar and was approximately 6 thousand $\mathrm{km}$ per one bus within a month. 
Table 1. Characteristics of operating fluids consumption during 57 months of operation

\begin{tabular}{|l|c|c|}
\hline & $\begin{array}{c}\text { Mercedes } \\
\text { Benz }\end{array}$ & $\begin{array}{c}\text { Solaris } \\
\text { Urbino }\end{array}$ \\
\hline Average mileage /1 bus x 1 month [km] & 5811 & 6081 \\
\hline Average fuel consumption/ 100 km x 1 bus[1] & 39,47 & 39,78 \\
\hline Average fuel consumption /100km acc. to standard x 1bus [1] & 40,99 & 39,99 \\
\hline Average fuel consumption with central heating /100 km x 1bus [1] & 40,87 & 41,17 \\
\hline Average AdBlue fluid consumption /1 bus x 1 m-c [1] & 86,9 & 10,3 \\
\hline $\begin{array}{l}\text { Average AdBlue fluid consumption specified by the manufacturer } \\
{\left[\mathrm{dm}^{3} / 100 \mathrm{~km}\right]}\end{array}$ & 1,3 & 0,21 \\
\hline Average engine oil consumption/1 bus x 1 m-c [1] & 2,92 & 4,16 \\
\hline
\end{tabular}

Average fuel consumption per month of operation of 1 vehicle for both brands is comparable and is above $39 \mathrm{l} / 100 \mathrm{~km}$. Fuel consumption for central heating in winter season increases for approximately $1.5 \mathrm{l} / 100 \mathrm{~km}$. A significant part in costs of operating fuels is AdBlue fluid costs. A monthly consumption of AdBlue is approx. 86.91 for Mercedes buses and 10.31 for Solaris.

\section{Failure characteristics}

Analysis included failures of all systems and structural units of the studied buses. Figure 1 presents average failure number per 1 vehicle within 1 month of operation. Investigated frequency of failure occurrence in the whole studied period of 57 months was about 3.16 for Solaris Urbino 12 and 2.23 for Mercedes Benz. Whereas during first 24 months (thus during warranty period) it was approx. 3.27 for Solaris and 2.85 for Mercedes buses. Considering period from 25 to 57 month of operation the value was 3.0 for Solaris bus and 1.7 for Mercedes vehicles. As it can be seen in the whole studied operating period less failures of Mercedes buses than Solaris buses were observed. While a significant decrease in the frequency of Mercedes buses failure occurred between 24 to 57 month of operation.

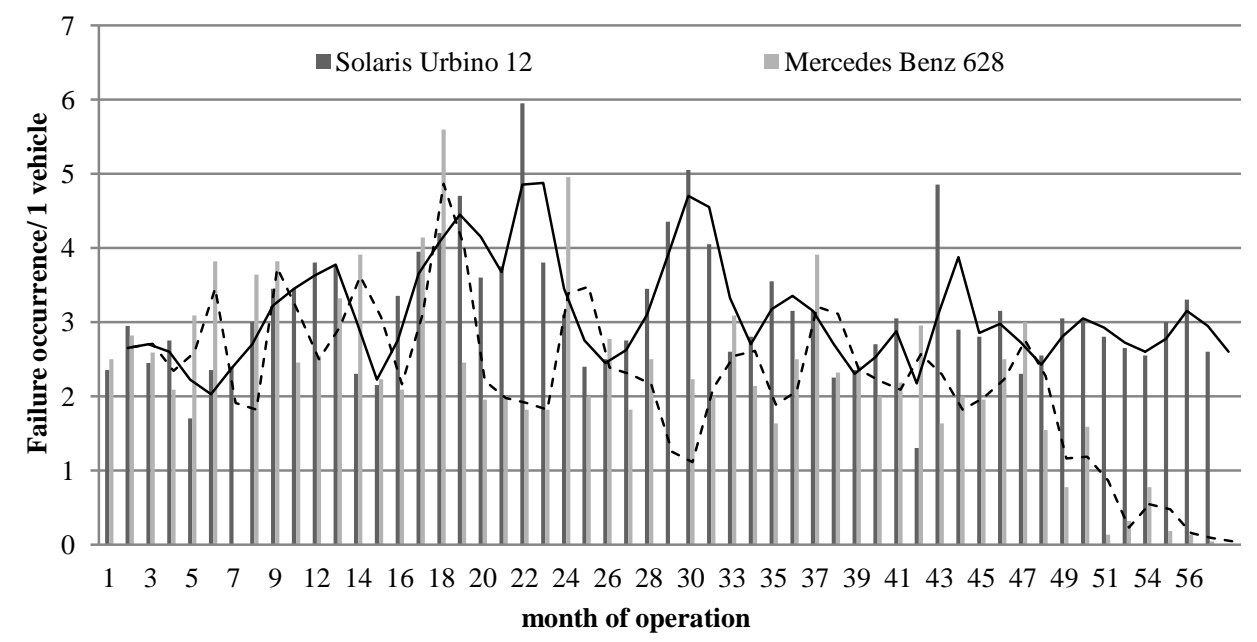

Fig. 1 Frequency of vehicle failures versus operating time 
Effectivness of the failure rate on maintenance costs of the city buses Wplyw częstości uszkodzeń na koszty utrzymania autobusów komunikacji miejskiej

\section{Technical availability characteristics}

From the user point of view besides the failure number, time for troubleshooting is also of high importance. For troubleshooting time the analysis of availability factor was used. It was assumed that the time of incapacity equalled the time needed for troubleshooting. In the conducted studies the availability was defined based on the following formulas [16]:

$$
K_{g}(t)=\frac{E(T)}{E(T)+\mathrm{E}(\Theta)}
$$

where:

$\mathrm{E}(\mathrm{T})$ - expected value of random variable of technical object of technical object usability time,

$\mathrm{E}(\Theta)$ - expected value of random variable of unavailability time of technical object (renewal and time to renewal),

Directly for calculations a simplified formula was used:

$$
K_{g}=\frac{T_{z}}{T_{z}+\mathrm{T}_{\mathrm{n}}}
$$

where:

$\mathrm{Tz}$ - average time of being available,

Tn - average time of being unavailable.

Technical availability factors of Solaris and Mercedes buses versus calendar time are presented in figure 2. The average availability of buses of both brands in the whole analysed operating period remained at the similar level and for the whole period of 57 months was 0.875 for Solaris buses and 0.909 for Mercedes Benz. It is worth mentioning that in the first and especially third quarter of each year the technical availability of both analysed types of vehicles decreased even to approx. 0.7.

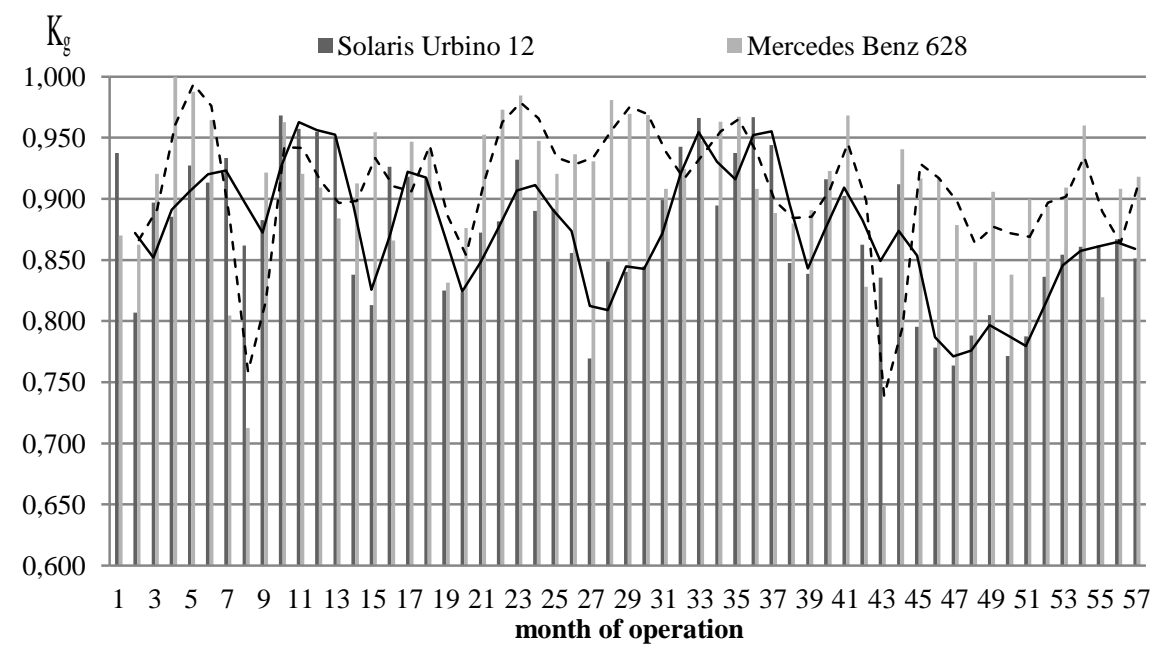

Fig. 2 Technical availability $K_{g}$ versus operating time 
In the first operating period i.e. till to approx. 14 month the technical availability for Solaris buses was about 0.91. Afterwards their availability was decreasing reaching a minimum value of 0.764 in 47 month of operation. It can be noticed that in 8 and 43 month of operation the technical availability of Mercedes buses was reaching the lowest values, 0.712 and 0.649 , respectively, which resulted from a prolonged waiting time for spare parts.

\section{Characteristics of the operating time}

\section{Repair costs}

From the previous considerations it can be concluded that Mercedes buses more rarely fail. Usually they are fixed in a shorter time (except the situations where it is necessary to wait for the spare parts). Repair time is a period when the vehicle does not make the money, while the owner is bearing the additional costs. In such context the analysis of the repair costs was conducted. The average monthly cumulated repair costs of the studied vehicles within the whole considered period were analysed.

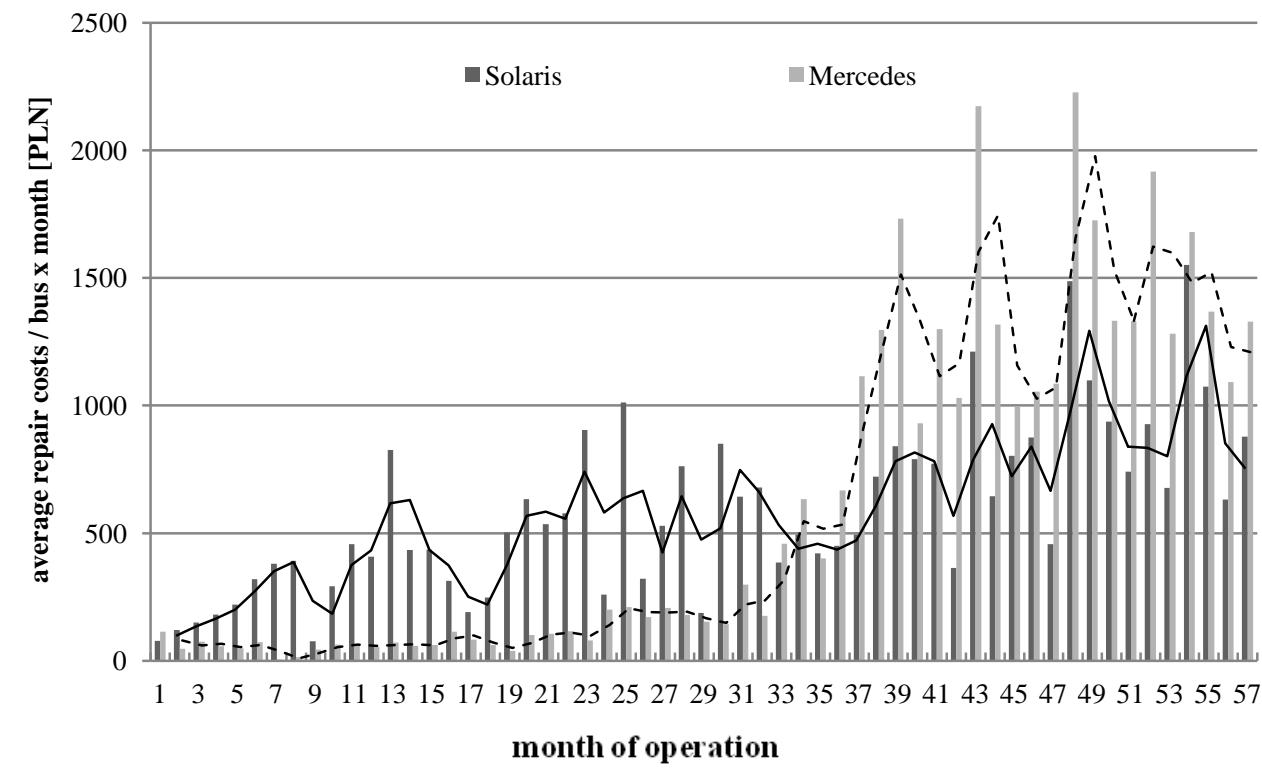

Fig. 3 Monthly repair costs per 1 bus [PLN]

Average monthly repair costs in the first two years of operation (including warranty period), thus till 24 month differ significantly and are 372 zloty and 73 zloty for Solaris and Mercedes, respectively (Figure 3). In after warranty period, thus between month 24 and 57 of the operation the difference between repair costs is lower and is 252 zloty (749 zloty for Solaris and 1000 zloty for Mercedes). 
Effectivness of the failure rate on maintenance costs of the city buses Wptyw częstości uszkodzeń na koszty utrzymania autobusów komunikacji miejskiej

It is worth stressing that between 33 and 57 month of operation the repair costs of Mercedes buses are approx. 1200 zloty per 1 vehicle per 1 month, thus exceeding repair costs of Solaris buses.

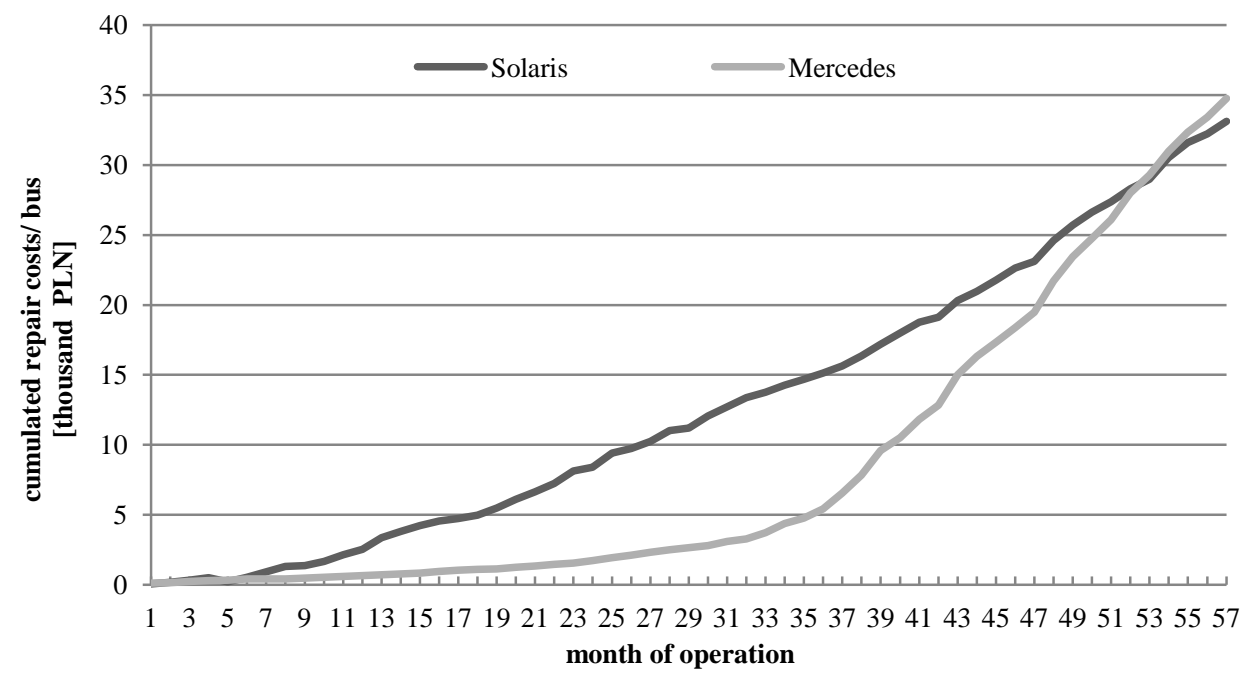

Fig. 4 Cumulated repair costs per 1 bus [PLN]

Figure 4 presents cumulated repair costs per 1 bus. After 57 months of operation the total costs of repair service per 1 vehicle is 33111 zloty for Solaris buses and 34755 zloty for Mercedes buses. From the user point of view a shape of the curve showing the cumulative repair costs is important. As it can be seen from the figure in case of Mercedes buses after 33 month of operation the costs start growing rapidly exceeding value of the cumulated repair costs of Solaris buses after about 53 months of operation.

Conducted analyses of the repairs excluded parts which failures were not related to the age (mileage) of the vehicle (e.g. mirrors, windows, safety hammers, license plate frames, replaced due to mechanical failures or theft), as well as the one being supplements installed per request of MPK Lublin (e.g. LCD screens, naturals).

\section{Service costs}

Analysis of the service costs is a significant component of the analysis of the full operating costs of the buses. The average service costs in the first two years of operation, thus until 24 month of operation are comparable and are 135 zloty and 143 zloty for Solaris and Mercedes buses (fig.5). In after warranty period, thus between 24 and 57 month of operation the difference between service costs is higher and is 52 zloty (378 zloty for Solaris and 325 zloty for Mercedes buses). 
It could be stressed that in 36 month of operation the service costs for Mercedes buses increased to 1091 zloty, and for the next two months remained at level of 724 and 606 zloty.

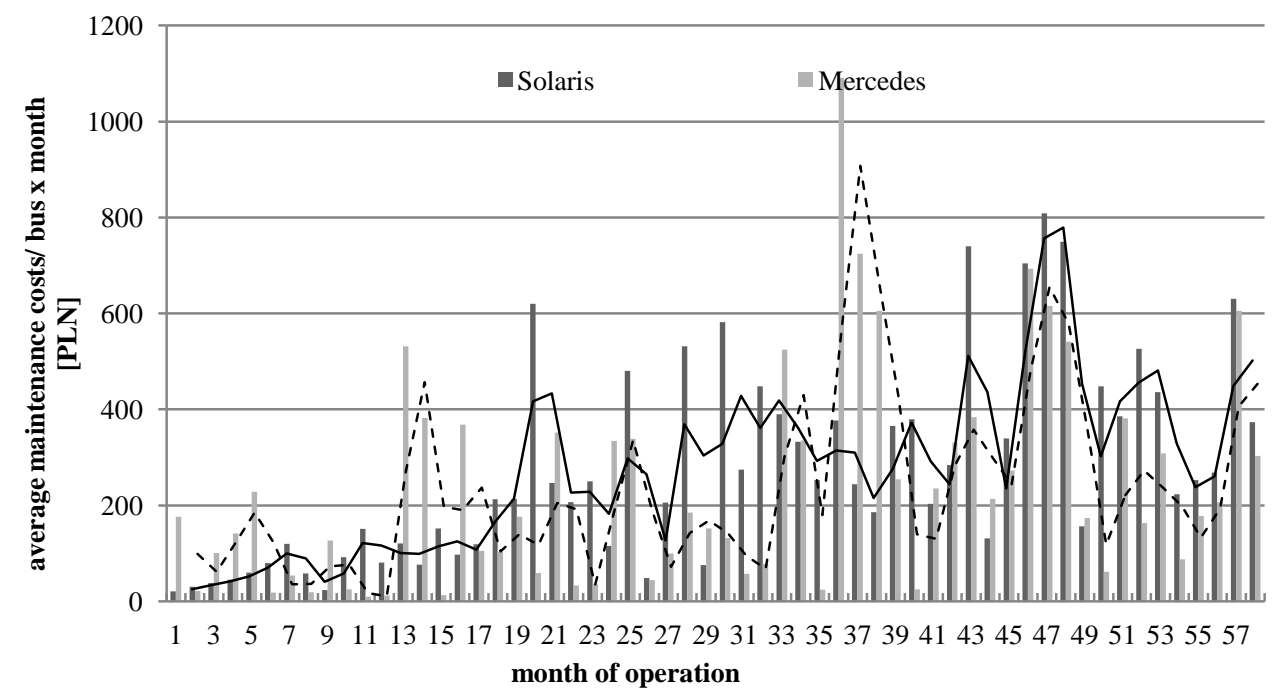

Fig. 5 Monthly maintenance costs per 1 bus [PLN]

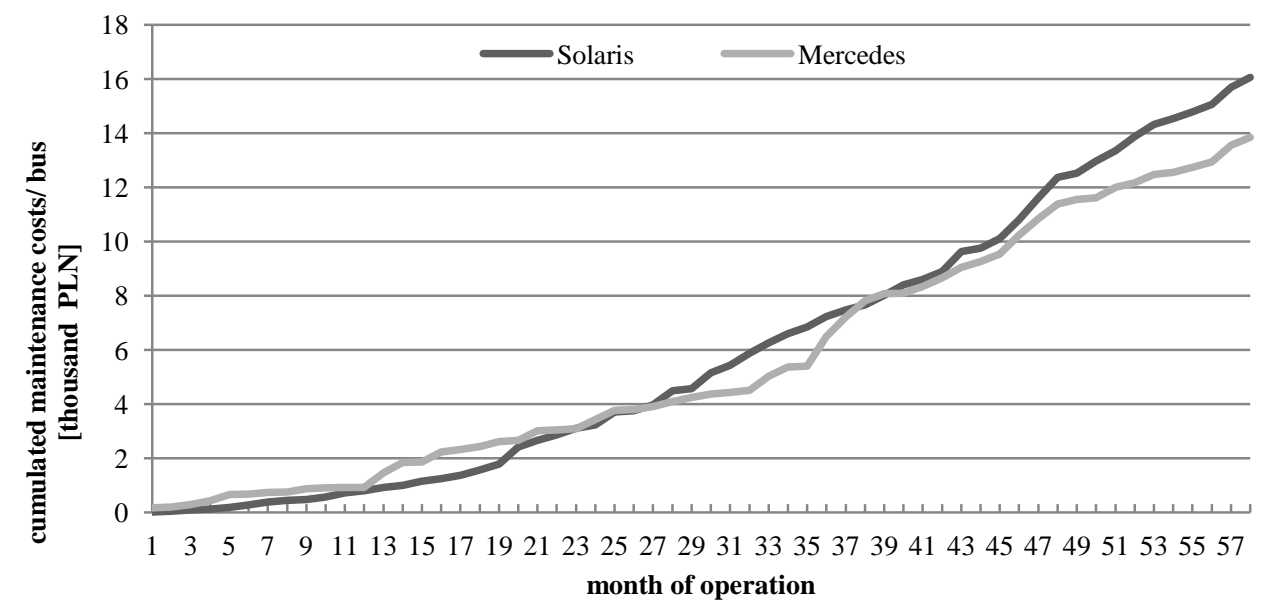

Fig. 6 Cumulated maintenance costs per 1 bus [thousand PLN]

Figure 6 presents cumulated costs of technical service per 1 bus at a certain month of operation. After 57 months of operation total service costs per 1 vehicle is 16 068 zloty for Solaris buses and 13858 zloty for Mercedes buses. Growth rate of the service costs is similar for both brands. 
Effectivness of the failure rate on maintenance costs of the city buses

Wptyw częstości uszkodzeń na koszty utrzymania autobusów komunikacji miejskiej

\section{Conclusion}

Failures related to operation of Solaris buses occurred more often than failures of Mercedes buses. It was proofed by the difference in monthly number of failures.

Technical availability of both brands was comparable, although there was a lower number of failures of Mercedes buses. However in this case, there was a longer waiting time for spare parts.

Frequency of failures as a function of time for Solaris buses indicates that failure frequency remain stable in the whole studied operating time, while for Mercedes buses failure frequency decreases after 48 months of operations.

Repair cost distribution analysis as a function of time indicates in case of Solaris buses, that the costs increase proportionally to operating time. In case of Mercedes buses a rapid growth of costs after 34 months operating time was observed.

The cumulated repair costs per 1 bus after 57 months of observation are higher in case of Mercedes buses, although total lower number of failures.

In the studied operating period Mercedes Benz 628 and Solaris Urbino 12 generated similar operating costs related to fuel and operating liquids consumption, as well as cost related with necessity of performing scheduled maintenance works.

\section{Bibliography}

[1] Aksezer C. S.: Failure analysis and warranty modelling of used cars. Engineering Failure Analysis, 18/2011, s. 1520-1526.

[2] Chukova S, Arnold R, Wang DQ.: Warranty analysis: an approach to modelling imperfect repairs. Int J Prod Econ, 89(1)/2004, s. 57-68.

[3] Gołąbek A.: Niezawodność autobusów. Wydawnictwo Politechniki Wrocławskiej, Wrocław 1993.

[4] Grabski F., Jaźwiński J.: Funkcje o losowych argumentach w zagadnieniach niezawodności, bezpieczeństwa i logistyki. WKiŁ, Warszawa 2009.

[5] Grądzki R., Lindstedt P.: Metoda oceny stanu zdatności obiektu technicznego w otoczeniu warunków użytkowania i obsługi. Eksploatacja i Niezawodnosc Maintenance and Reliability, 1/2015, 54-63.

[6] Kleynera A., SandbornP.: A warranty forecasting model based on piecewise statistical distributions and stochastic simulation. Reliability Engineering and System Safety, 88/2005, s. 207-214.

[7] Majeske K. D.: A non-homogeneous Poisson process predictive model for automobile warranty claims. Reliability Engineering and System Safety, 92/2007, s. 243-251.

[8] Matuszak Z.: Problemy badania niezawodności siłowni transportowych obiektów oceanotechnicznych, Autobusy 6/2010.

[9] Michalski R., Wierzbicki S.: Badania porównawcze niezawodności autobusów komunikacji miejskiej. Eksploatacja i Niezawodność - Maintenance and Reliability, 4/2006, s. 22-26.

[10] Murthy D.N.P., Djamaludin I.: New product warranty: A literature review. Int. J. Production Economics, 79/2002, s. 231-260. 
[11] Naikan VNA, Kapur S.: Reliability modelling and analysis of automobile engine oil. Proc IMechE Part D: J Automob Eng 220(2)/2006, s. 187-94.

[12] Pecht M.: Establishing a relationship between warranty and reliability. IEEE Trans Electron Packag Manuf, 29(3)/2006, s. 184-90.

[13] Rymarz J., Niewczas A.: Ocena niezawodności eksploatacyjnej autobusów komunikacji miejskiej. Problemy Eksploatacji - Zeszyty Naukowe Instytutu Technologii Eksploatacji - PIB, Radom 1/2012.

[14] Rymarz J., Niewczas A., Pieniak D.: Reliability analysis of the selected brands of city buses at municipal transport company, Journal of KONBiN 2(26)2013, s. $111-122$

[15] Shafiee M., Chukova S.: Maintenance models in warranty: A literature review. European Journal of Operational Research, 229/2013, s. 561-572

[16] Woropay M., Szubartowski M., Migawa K., Model oceny i kształtowania gotowości operacyjnej podsystemu wykonawczego w systemie transportowym. Wydawnictwo i Zakład Poligrafii Instytutu Technologii Eksploatacji, Radom 2003

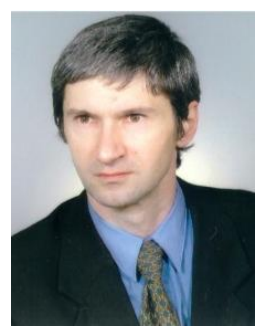

PhD. Eng. Piotr Ignaciuk graduated from Lublin University of Technology, Faculty of Mechanics. He earned a doctoral degree in the area of operation and machines construction in 1998. His research area is related to reliability and engine and car wear processes. As an editor of fuel, oil and lubricants section of monthly "Special cars" he is involved in promoting activities.

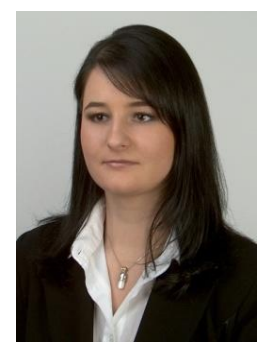

M.Sc. Eng. Joanna Rymarz, received her M.Sc. in 2008 from Lublin University of Technology (LUT). From 2008 researcher and since 2009 assistant at Faculty of Mechanical Engineering at LUT. She is involved in research in the areas of reliability, maintenance, availability and safety of transport system operation.

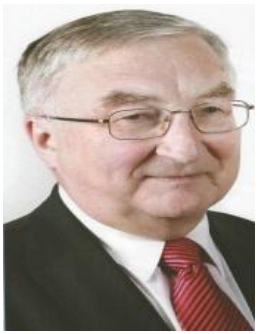

Prof. Andrzej Niewczas, PhD. Eng. is a professor at Faculty of Mechanical Engineering in Lublin University of Technology. In his research he deals with problems connected with construction and maintenance machines and transport systems. Additionally professor Niewczas is a President of the Polish Maintenance Society. 
Effectivness of the failure rate on maintenance costs of the city buses Wptyw częstości uszkodzeń na koszty utrzymania autobusów komunikacji miejskiej 